\title{
Evaluating Haricot Bean Cultivars (Phaseolus vulgaris L.) for Growth and Dry Matter Production
}

\author{
Fikir Desalew* \\ Seed Science and Technology, Holetta Agricultural Research center, Holetta, Ethiopia \\ *Corresponding Authors: Fikir Desalew, Seed Science and Technology, Holetta Agricultural Research
} center, Holetta, Ethiopia

\begin{abstract}
Growth and type of cultivar are important for good agronomic performance and production of dry matter in haricot bean (Phaseolus vulgaris L.). Five haricot bean cultivars were grown in randomized complete block design with three replications during 09/04/2019 - May 23/05/2019 at Hawassa University Agricultural College, Southern Ethiopia. The objective of the study was to evaluate the performance of haricot bean cultivars based on growth analysis data. Data were specific leaf area ratio, leaf area ratio, net assimilation rate, and relative growth rate and plant height and leaf area. There is no significant difference among cultivars observed for all the parameters except leaf area of the first sampling.
\end{abstract}

Keywords: Growth parameters, Cultivars, Dry matter, Haricot bean

\section{INTRODUCTION}

Haricot bean(Phaseolus vulgaris L.) belongs to order Rosales, family Leguminosae, subfamily Papilionideae, tribe Phaseolea, subtribe Phaseolinae, genus Phaseolus (CIAT, 1986a) locally known as 'Boleqe' also known as dry bean, common bean, kidney bean and field bean is a very important legume crop grown worldwide. It is annual, herbaceous plant with various growth habits, morphological traits, and seed and pod characteristics. The bean flower is perfect, possessing both male and female organs on the same flower, and is self fertilized. Pollination overlaps with the time when the flower opens (Purseglove, 1968). It is originated in tropical America. Genetic diversity of the materials that exists in this region is the main verification their origin.

The crop is adapted to an altitude ranging from sea level to nearly 3000 m.a.s.l (CIAT, 1986a). Suitable production areas of bean in Ethiopia have been indicated as areas with an altitude between 1200 - 2200 m.a.s.l, mean maximum and mean minimum temperature of less than 30-320 $\mathrm{C}$ and greater than 10 -120 C, respectively, and a rainfall of 350-500 mm well distributed over 70-100 days (Amare and Haile, 1989). It is known as the second most important source of human dietary protein and the third most important source of calorie of all the agricultural commodities produced in eastern and southern Africa (Kimani, 1999). Different cultivars have different growth parameter performance. Understanding the performance of different Haricot bean cultivar is critically vital in crop production. Thus, the experiment was conducted to evaluate the performance of haricot bean cultivars based on growth analysis data.

\section{MATERIALS AND METHODS}

\subsection{Description of the Study Area}

The experiment was conducted at Hawassa University College of Agriculture, Ethiopia. It is located $270 \mathrm{~km}$ south of Addis Ababa. A field trial was conducted from April 9/04/2019 to may 23/05/2019 under controlled water supply at experimental field of Hawassa University college of Agriculture. The site is located $6^{\circ} 42^{\prime} \mathrm{N}$ and $38^{\circ} 29^{\prime} \mathrm{E}$ of latitude at an altitude of 1650 m.a.s.l with mean annual rainfall of $900 \mathrm{~mm}$, mean annual temperature maximum and minimum of $13^{\circ} \mathrm{C}$ and $27^{\circ} \mathrm{C}$ respectively.

\subsection{Experimental Materials}

The experiment consisted of 5 haricot bean cultivars i.e., Hawassa dume, Ibbado, SER-119, SER-125, and Nassir haricot bean Cultivars. 


\subsection{Experimental Design and Field operations}

The experiment was laid out in randomized complete block design (RCBD) with three replications at Hawassa University College of Agriculture. A Spacing of $40 \mathrm{~cm}$ between rows and plants were spaced $10 \mathrm{~cm}$ apart. To ascertain full stand in a plot, two seeds per hill were planted and thinned to appropriate stand 10 days after emergence. A plot of five rows each $2 \mathrm{~m}$ long $(2 \mathrm{~m} \times 2 \mathrm{~m})$ was used, and $50 \mathrm{~kg} / \mathrm{ha}$ DAP fertilizer was applied at the time of planting. All necessary agronomic practices have been done uniformly as per the recommendations. The cultivars were planted on April 9, 2019 and first and second samples were taken on May 10, 2019 and may 23, 2019 respectively.

Destructive sampling at 20 and 33 days after emergence was taken by randomly selecting three plants per plot to measure leaf area, leaf dry weight, stem dry weight and plant height. During sampling, a representative row from the plot was selected and all above ground part was harvested. After separating leaf and stem, the leaf area was measured by portable leaf area meter and plant height by ruler. Leaf and stem dry weight was separately obtained after dried in oven dry for $48 \mathrm{hr}$ at $72^{\circ} \mathrm{C}$.

The remaining data was obtained by calculation as $1^{\text {st }}$ leaf area (LA1), $2^{\text {nd }}$ leaf area (LA2), leaf dry weight $\left(\mathrm{W}_{\text {leaf } 1}\right.$ and $\left.\mathrm{W}_{\text {leaf } 2}\right)$, Leaf area ratio $\left(\mathrm{LAR}_{1}\right.$ and $\left.\mathrm{LAR}_{2}\right)$,Specific leaf area(SLA1 and SLA2 ), Total dry weight(WI and W2) Net assimilation rate(NAR), Relative growth rate (RGR)were as: $\mathrm{SLA}=\mathrm{A} / \mathrm{W}_{\text {leaf }}, \mathrm{LAR}=\mathrm{A} / \mathrm{W}, \mathrm{NAR}=(\mathrm{W} 2-\mathrm{W} 1)(\ln \mathrm{A} 2-\ln \mathrm{A} 1) /(\mathrm{A} 2-\mathrm{A} 1)(\mathrm{T} 2-\mathrm{T} 1), \mathrm{RGR}=(\ln \mathrm{W} 2-\ln \mathrm{W} 1) /(\mathrm{T} 2-$ $\mathrm{T} 1$ ), Where $\mathrm{A}=$ leaf area, $\mathrm{P}=$ ground area, $\mathrm{W}_{1}$ and $\mathrm{W}_{2}=$ total dry weight of sampling time ${ }_{1}$ and ${ }_{2}$ respectively.

\subsection{Data Collected}

Data were recorded on individual plant basis for the following parameters to represent their respective characters.

\subsubsection{Data collected on individual plant basis}

1. Plant height $(\mathrm{cm})$ : The average height of three randomly taken plants in centimeters measured from the soil surface to the top of the canopy of the plant.

2. Leaf area $(\mathrm{cm} 2)$ : The average leaf area of three randomly taken plants in

Centimeters square measured from the soil surface to the top of the canopy of the plant.

3. Dry weight (gm): The average weight of three randomly taken plants in gram measured from the soil surface to the top of the canopy of the plant.

\section{RESUlT AND DisCUSSION}

\subsection{Leaf Area Ratio}

Leaf area ratio (LAR) is the ratio between leaf area and total plant dry weight. When LAR value recorded high, it has been considered a desirable characteristic because it indicated the plant had a high photosynthetic potential in relation to its respiratory load. (Wallace and Munger, 1965) indicates that the yields of haricot bean cultivars were more highly correlated with their LAR than with either their LAI. In the other case, (Buttery and Buzzell, 1972) reported that selection for high yielding soybean cultivars had alongside reduced the LAR. The statistical analysis of leaf area ratios (LAR) is summarized in Table 1. The LAR of all cultivars declined as crop development progressed. But, the differences in LAR among the cultivars were relatively small. The LAR of Nassir $\left(155.45 \mathrm{~cm}^{2} \mathrm{~g}^{-1}\right)$ was better than Hawassa Dume $\left(154.02 \mathrm{~cm}^{2} \mathrm{~g}^{-1}\right)$, Ibbado $\left(151.22 \mathrm{~cm}^{2} \mathrm{~g}^{-1}\right)$, SER-119 $\left(142.54 \mathrm{~cm}^{2} \mathrm{~g}^{-1}\right)$, SER-125(138.60 $\left.\mathrm{cm}^{2} \mathrm{~g}^{-1}\right)$ correspondingly in the first sampling date. While, SER-119 $\left(195.02 \mathrm{~cm}^{2} \mathrm{~g}^{-1}\right)$ was better than Nassir $\left(158.61 \mathrm{~cm}^{2} \mathrm{~g}^{-1}\right)$, Hawassa Dume $\left(149.37 \mathrm{~cm}^{2} \mathrm{~g}^{-1}\right)$, SER-125 $\left(130.43 \mathrm{~cm}^{2} \mathrm{~g}^{-1}\right)$, Ibbado $\left(126.53 \mathrm{~cm}^{2} \mathrm{~g}^{-1}\right)$ correspondingly in the second sampling. There was fluctuation concerning LAR in all cultivars. The cultivar that showed higher LAR in the first sampling was not in the second sampling.

Table1. Mean growth parameters (LAR) of different Haricot bean cultivars

\begin{tabular}{|l|l|l|}
\hline \multirow{2}{*}{ Cultivars } & LAR $\left(\mathrm{cm}^{2} \mathrm{~g}^{-1}\right)$ \\
\cline { 2 - 3 } & First Sampling & Second Sampling \\
\hline Hawassa Dume & $154.02 \pm 3.87$ & $149.37 \pm 34.42$ \\
\hline Ibbado & $151.22 \pm 0.98$ & $126.53 \pm 5.48$ \\
\hline
\end{tabular}




\begin{tabular}{|l|l|l|}
\hline SER-119 & $142.54 \pm 16.71$ & $195.02 \pm 32.75$ \\
\hline SER-125 & $138.60 \pm 2.98$ & $130.43 \pm 4.34$ \\
\hline Nassir & $155.45 \pm 5.4$ & $158.61 \pm 3.55$ \\
\hline
\end{tabular}

\subsection{Specific Leaf Area}

Specific leaf area (SLA) is the ratio of leaf area to leaf dry weight. The SLA has been shown to change during the course of crop development. Numerical differences have been noted in SLA among cultivars, not statistically. (Buttery and Buzzell, 1972) compared parent soybean cultivars with their progeny and found that selection for improved yield had in tandem reduced SLA, recommended the use of this parameter as a selection criterion. The statistical analysis of specific leaf area (SLA) has been summarized in Table 2. The SLA Ibbado declined while the rest four cultivars increased as crop development progressed. But the differences in SLA among the cultivars were relatively small.

Table2. Mean growth parameters (SLA) of different Haricot bean cultivars

\begin{tabular}{|l|l|l|}
\hline \multirow{2}{*}{ Cultivars } & \multicolumn{2}{|l|}{ SLA $\left(\mathrm{cm}^{2} \mathrm{~g}^{-1}\right)$} \\
\cline { 2 - 3 } & First Sampling & Second Sampling \\
\hline Hawassa Dume & $205.52 \pm 4.33$ & $267.02 \pm 78.01$ \\
\hline Ibbado & $228.49 \pm 4.61$ & $209.12 \pm 75.76$ \\
\hline SER-119 & $198.91 \pm 22.84$ & $320.35 \pm 50.24$ \\
\hline SER-125 & $201.18 \pm 1.95$ & $228.53 \pm 6.19$ \\
\hline Nassir & $218.17 \pm 10.02$ & $256.67 \pm 4.14$ \\
\hline
\end{tabular}

\subsection{Net Assimilation Ratio}

The net assimilation rate (NAR) defined as the rate of increase of dry weight per unit of leaf area. The NAR of Phaseolus vulgaris L. during early development, has been near $80 \mathrm{mg} / \mathrm{dm} 2 /$ day (Wallace and Munger, 1965). In this experiment, $263.09 \mathrm{mg} / \mathrm{dm} 2 /$ day was maximum. Several studies have found a negative correlation between leaf area ratio and NAR. The rate of decline in LAR per unit increase in NAR has been used as a measure of the canopy efficiency of crops. (Watson and Witts, 1959) reported the NAR of improved cultivars showed a slower rate of decline than the older standard ones. They attributed this to improvements of canopy architecture. (Watson 1952) predicted that cultivars with a higher LAR would have a higher NAR. (Dornhoff and Shibles et al., 1970) theorized that low SLA may be associated with a high cell surface to volume ratio, therefore, alower mesophyll resistance to $\mathrm{CO}$ diffusion.

The relative NAR of the cultivars depended on the stage of crop development (Table 3). During the two sampling period, the NAR of Hawassa dume was the other cultivars.

\subsection{Relative Growth Rate (RGR)}

Relative growth rate is the rate of increase in plant dry weight relatively to the total dry weight of that plant. The relative RGR of the cultivars depended on the stage of crop development (Table 3). During the sampling period, the RGR of Hawassa dume was better than the other four cultivars.

Table3. Mean growth parameters (NAR, and RGR) of different Haricot bean cultivars

\begin{tabular}{|l|l|l|}
\hline Cultivars & NAR $\left(\mathrm{mg} \mathrm{dm}^{-2} \mathrm{day}^{-1}\right)$ & RGR $\left(\mathrm{mg} \mathrm{g}^{-1}\right.$ day $\left.^{-1}\right)$ \\
\hline Hawassa Dume & $263.09 \pm 10.15$ & $92.91 \pm 3.14$ \\
\hline Ibbado & $184.69 \pm 7.35$ & $52.60 \pm 5.86$ \\
\hline SER-119 & $222.18 \pm 1.02$ & $85.85 \pm 1.56$ \\
\hline SER-125 & $205.42 \pm 2.73$ & $77.21 \pm 0.37$ \\
\hline Nassir & $212.78 \pm 1.08$ & $85.69 \pm 1.53$ \\
\hline
\end{tabular}

\section{CONCLUSiON}

Dry matter production of crops can be influenced by genetic factor. Haricot bean (Phaseolus vulgaris L.) cultivar type are important for good agronomic performance for greater production of dry matter production. In this experiment, the relative NAR of the cultivars depended on the stage of crop development (Table 3). The SLA has been shown no constant change during the course of crop development. The RGR of the cultivars depended on the stage of crop development .During the period, between two sampleing dat, the RGR of Hawassa dume was better than the other cultivars numerically.But, statistically no significant difference. Thus, this experiment showed that of the 
performance haricot bean cultivars in the study area may not lead us to the final conclusion rather further sampling and investigation is needed.

\section{REFERENCES}

[1] Amare Abebe and Haile Kefene, (1989). Country reports Eastern Africa. Ethiopia. p. 110-120. beans (Phaseolus vulgaris L.) in West Asia and North Africa. Aleppo, Syria. 1983. Cali, brief note, University of Nairobi, Department of Crop Sciences, Nairobi, Kenya.

[2] Buzzell, R.I., (1972). Some differences between soybean cultivars observed by growth analysis. Can. J.Plant Sci. 52:13-20.

[3] Centro International de Agricultura Tropical (CIAT), (1986a). The cultivated species of phaseoulus: study guide to be used as supplement to the audotutorial unit on the same topic.Cali, Colombia. CLAT.

[4] Dornhoff, G. M., and R. M. Shibles. (1970). Varietal difference in net photosynthesis of soybean leaves. Crop Sci. 10:42-45.

[5] Kimani P.M.,( 1999.) Common Bean in Africa. Its origin, production, and improvement, a Neth. J. Agr. Sci. 10 (special issue):361-376.

[6] Purseglove, J.W., (1968). Tropical crops: Dicotyledons 1. Longmans Green and Co. Ltd. Wallace, D. H., and H. M. Munger. (1965). Studies of the physiological basis for yield differences. I. Growth analysis of dry bean varieties. Crop Sci. 5:343-348.

Citation: Fikir Desalew, (2021). "Evaluating Haricot Bean Cultivars (Phaseolus vulgaris L.) for Growth and Dry Matter Production", International Journal of Research Studies in Agricultural Sciences (IJRSAS), 7(9), pp. 13-16 DOI: http://dx.doi.org/ 10.20431/2454-6224.0709003

Copyright: () 2021 Authors. This is an open-access article distributed under the terms of the Creative Commons Attribution License, which permits unrestricted use, distribution, and reproduction in any medium, provided the original author and source are credited. 